\title{
Carbon Emissions, Energy Consumptions, and Production Activity: Now and Future
}

\author{
Dwiputra Ahmad Ramdani \\ Center of Policy Analysis \\ Ministry of National Development Planning \\ Jakarta, Indonesia \\ dwiputra.ramdani@gmail.com
}

\author{
Gisty Ajeng Septami \\ Center of Policy Analysis \\ Ministry of National Development Planning \\ Jakarta, Indonesia \\ agiseptami@gmail.com
}

\begin{abstract}
Most of the countries in the world, including Indonesia, have agreed to take action of keeping global warming below $2^{\circ}$ Celsius in this century, as ratified in the Paris Agreement. Indonesia is committed to reduce their greenhouse gasses (GHG) emissions by $29 \%$ in 2030 without any international support. This study aims to analyze the nexus between carbon emission, energy consumption, and economic productivity; and moreover, identifies which factor in Kaya identity that affects more to the carbon emission. By employing energy and emission data from International Energy Agency (IEA), and macroeconomic data of 34 Provinces from Central Bureau of Statistics (BPS), three dynamic models confirm that there is causality between those three variables.

Decomposition results of Kaya identity showed that during 1993-2014, there was an increasing trend of carbon emissions mostly affected by carbon efficiency (ratio of $\mathrm{CO}_{2}$ emitted per energy consumption) and economic productivity. On the other hand, energy intensity of economy showed a promising decline trend over this period, indicating that less energy was needed to get a rupiah of GDP. Assuming the growth rate of GDP per capita is steady at $3 \%$ per year, Indonesia needs to further reduce its carbon content of energy at $4.5 \%$ per year and energy intensity at $\mathbf{2 \%}$ per year, so that the INDC target in 2030 can successfully be achieved.
\end{abstract}

Keywords - economic growth; energy consumption; carbon emissions; kaya identity; dynamic panel data

\section{INTRODUCTION}

Indonesia commits in reducing carbon emission by implementing the issuance of the National Energy Policy (KEN) in Presidential Decree No. 79/2014. In March 2017, President Joko Widodo signed a presidential regulation on the General Planning for National Energy (RUEN) elaborating the action plan of national energy policy. In this policy, the renewable energy is still targeted to account for 23 percent of Indonesia's total energy consumption. This target seems reasonable, considering renewable energy accounted for 23 percent of global electricity generation in 2015 [1], Indonesia still struggled to have a steady growth of renewable energy share in the past few years. In 2016, share of renewable energy in primary energy mix was only $6.51 \%$ or only increased 2 percentage points in 2 years [2].

The slow growth of renewable energy in Indonesia can be understood considering the economic condition of Indonesia that is still growing in average of $5.3 \%$ per year for the past decade [3]. This situation is seemingly resembled the Environmental Kuznetz Curve (EKC) that said environmental degradation tend to get worse until the income per capita reaches a certain point, assuming Indonesia is still on the leftside of the inverted $\mathrm{u}$-shape curve.

This study aims to analyze the nexus between GHG emissions represented by carbon emission, energy consumption, and economic productivity in Indonesia, while proofing the existence of EKC in Indonesian economy. After obtaining the causality nexus between those three variables, the study uses Kaya identity in order to identify which identity has dominan impact on Indonesia's carbon emissions. At the end, a policy recommendation on how the government should act in order to reach the National Determined Contributions (NDC) target of $29 \%$ emission reduction by 2030 is proposed.

\section{ANALYTICAL FRAMEWORK}

An analysis on relationship between $\mathrm{CO}_{2}$ emissions and GDP has been profoundly studied over the past decade. A previous study showed there is no causal relation between GDP and $\mathrm{CO}_{2}$ emissions [4], meanwhile others said that there is a unidirectional relation between those variables (which only GDP affecting the emissions) [5]. A study testing UAE data during 1975-2011 showed the presence of EKC along with the similar relationship between financial development and $\mathrm{CO}_{2}$ emissions [6]. Furthermore, a study in the Middle-East NorthAfrica (MENA) Net Oil Exporting Countries (NOEC) confirmed that there is bidirectional causality between energy consumption to economic growth [7].

\section{A. The Review of Production Function and Traditional Economics Model}

According to the economic theory, output, inputs and profits of a company (as well as, a country) are determined by the production function. Basically, a firm needs resources, equipment, supplies, and other inputs to produce something. A production function is a way of measuring what comes out of production to what has gone into it. In macroeconomics, the factors of production are classified into 4 (four) categories which are: (i) Capital Stock $(\mathrm{K})$, or tangible assets that are created to use in the production process. This includes machines, vehicles, buildings, and other equipment; (ii) Labor (L), or all human efforts in order to produce goods and services; 
(iii) Land (P), that includes natural resources, raw materials and energy sources; and (iv) Entrepreneurship (H), or the quality of the business intelligence to develop, organize, and manage a production process with any risks in order to make a profit.

Therefore, the production function is principally expressed in the formula of $\mathrm{Q}=\mathrm{f}(\mathrm{K}, \mathrm{L}, \mathrm{P}, \mathrm{H})$, where the amount produced is a function of the assembled input quantities of each factor. Another basic formula of this calculation is $Q=f(K, L)$, in which capital and labor are the two main factors of production with the greatest impacts on the output. This function is then known as the Cobb-Douglas production function. This equation would need to have the property that $\mathrm{F}(\mathrm{K}, \mathrm{L})=\mathrm{A} \mathrm{K}^{\alpha} \mathrm{L}^{(1-\alpha)}$ where $A$ is a productivity parameter explaining the advancement of technology, and $\alpha$ is a constant representing capital's share of income.

\section{B. Kaya Identity}

The Kaya identity is a formula expressing the total carbon emission level that can be stated in four inputs: human population, GDP per capita, energy intensity, and carbon intensity. This study uses a simplified version of Kaya identity that rules out the population factor as just part of the GDP, considering the growth of population in Indonesia is relatively constant at $1.5 \%$ per year [3]. The equation then can be expressed as follows:

$$
\mathrm{CO}_{2}=\frac{\mathrm{CO}_{2}}{\text { Energy }} \times \frac{\text { Energy }}{G D P} \times G D P
$$

In most Kaya identity analysis, the numbers of population and GDP are not really a useful way to limit the negative impacts on climate change because normally people still want their economy to grow. The proposal to discuss the effects on climate change then remains on the energy intensity of the economy and carbon content of energy.

\section{DATA AND METHODS}

In general, this study comprises of two methods: causality analysis using dynamic panel data and decomposition of Kaya identity. Three dynamic panel models are built by employing energy and emission data from IEA and macroeconomic data of 34 Provinces from BPS. The descriptive summary of the variables used can be seen in Table 1. Due to some regional expansion and/or segregation, some data could not perfectly cover all provinces in Indonesia.

\section{A. Estimation Methodology and Procedure}

An extended production function, adapted from Omri's model, is used as the main framework to develop three-way linkages model between $\mathrm{CO}_{2}$ emissions, economic growth, and energy consumption in Indonesia. The three models can be expressed as follows:

$$
\begin{aligned}
\ln \left(Y_{i t}\right)= & \alpha_{0}+\alpha_{1 i} \ln \left(E_{i t}\right)+\alpha_{2 i} \ln \left(C_{i t}\right)+\alpha_{3 i} \ln \left(K_{i t}\right)+ \\
& \alpha_{4 i} \ln \left(L_{i t}\right)+\pi_{i t} \\
\ln \left(E_{i t}\right)= & \beta_{0}+\beta_{1 i} \ln \left(Y_{i t}\right)+\beta_{2 i} \ln \left(C_{i t}\right)+\beta_{3 i} \ln \left(K_{i t}\right)+ \\
& \beta_{4 i} \ln \left(L_{i t}\right)+\beta_{5 i} \ln \left(C R_{i t}\right)+\varepsilon_{i t}
\end{aligned}
$$

TABLE I. SUMMARY OF VARIABLES

\begin{tabular}{lccccc}
\hline \multicolumn{1}{c}{ Variable / Units } & Obs. & Mean & Std. Dev. & Min. & Max. \\
\hline $\begin{array}{l}\text { Gross Regional Domestic Product* } \\
\text { (in Billion Rp) }\end{array}$ & 671 & $176,063.1$ & $242,093.7$ & $7,814.7$ & $1,373,390$ \\
$\begin{array}{l}\text { CO}_{2} \text { Emission** } \\
\text { (Kiloton CO } \text { }^{\text {Kilon }}\end{array}$ & 671 & $11,584.58$ & $14,911.49$ & 363.4 & $82,640.83$ \\
$\begin{array}{l}\text { Energy Consumption* } \\
\text { (Kiloton Oil Equivalent-TOE) }\end{array}$ & 671 & $4,210.896$ & $5,879.769$ & 210.81 & $27,993.76$ \\
$\begin{array}{l}\text { Gross Fixed Capital Formation** } \\
\text { (in Billion Rp) }\end{array}$ & 671 & $44,835.65$ & $77,488.93$ & 240.9505 & $638,377.7$ \\
$\begin{array}{l}\text { Trade Openness* } \\
\text { (Export and Import Ratio to GRDP) }\end{array}$ & 671 & 0.6787 & 0.3897 & 0.0015 & 1.9477 \\
$\begin{array}{l}\text { Population* } \\
\text { (in Thousand) }\end{array}$ & 670 & $7,025.252$ & $9,804.58$ & 551.017 & $46,029.6$ \\
$\begin{array}{l}\text { Labor Force* } \\
\text { (in Thousand) }\end{array}$ & 655 & $3,192.959$ & $4,519.264$ & 226.3531 & $19,306.51$ \\
Loan Ratio to GRDP* & 656 & 0.1326 & 0.1324 & 00.0049 & 0.8622 \\
\hline
\end{tabular}

Source: *) Central Bureau of Statistics, **) International Energy Agency

$$
\begin{aligned}
\ln \left(C_{i t}\right)= & \psi_{0}+\psi_{1 i} \ln \left(Y_{i t}\right)+\psi_{2 i} \ln \left(E_{i t}\right)+\psi_{3 i} \ln \left(T O_{i t}\right)+ \\
& \psi_{4 i} \ln \left(P O P_{i t}\right)+\lambda_{i t}
\end{aligned}
$$

Equation (2) shows that economic growth can be influenced by the energy consumption (E), $\mathrm{CO}_{2}$ emission (C), capital stock $(\mathrm{K})$, and total labor (L) [8] [9]. Equation (3) states that the energy consumption is derived from economic growth (Y), $\mathrm{CO}_{2}$ emission, capital stock, total labor, and ratio of total credit per GDP (CR) [8] [9] [10]. Equation (4) postulates that environmental degradation has a relationship between economic growth, energy consumption, trade openness (TO), and population (POP) [9] [10] [11].

In order to get the empiric estimation, this study employs dynamic simultaneous-equation models in (2), (3), and (4) by utilizing the one-period lagged levels of the three dependent variables - economic productivity, energy consumption per capita, and $\mathrm{CO}_{2}$ emissions per capita-with assumption that the current levels of each dependent variables are somewhat depend on each previous condition. This study adapts the dynamic models with panel data using the Arellano and Bond Generalized Method of Moments (GMM) estimator [12]. This approach averts the biases as well as the endogeneity problem of the regressors by using a set of Instrumental Variables (IV). The GMM has also been proven robust to arbitrary heteroskedasticity. Furthermore, this study analyses those equations by using the ordinary least squares (OLS) method.

\section{B. Decomposition Analysis}

According to (1), the changes of carbon emissions from base year to a certain year can be expressed as follows:

$$
\Delta C O 2_{T}=C O 2_{T}-C O 2_{0}=\Delta C_{c n t}+\Delta E_{\text {int }}+\Delta \mathrm{GDP}
$$

where $\Delta C_{T}$ denotes the total effects of carbon emission changes, $\Delta C_{c n t}$ denotes the carbon content of energy. In order to identify the impacts on total carbon emissions from those three factors, the decomposition of simplified Kaya identity utilizes Logarithmic Mean Divisia Index (LDMI) that can be formulated as follows:

$$
L\left(C O 2_{i}^{T}, C O 2_{i}^{0}\right)=\frac{\mathrm{CO}_{T}-\mathrm{CO}_{0}}{\ln \left(\frac{\mathrm{CO} 2}{\mathrm{CO}_{0}}\right)}
$$




$$
\begin{gathered}
\Delta C_{c n t}=\sum_{i=1}^{34} L\left(C O 2_{i}^{T}, C O 2_{i}^{0}\right) \times \ln \left(\frac{C_{i}^{T}}{C_{0}^{T}}\right) \\
\Delta E_{\text {int }}=\sum_{i=1}^{34} L\left(C O 2_{i}^{T}, C O 2_{i}^{0}\right) \times \ln \left(\frac{E_{i}^{T}}{E_{0}^{T}}\right) \\
\Delta G D P=\sum_{i=1}^{34} L\left(C O 2_{i}^{T}, C O 2_{i}^{0}\right) \times \ln \left(\frac{G D P_{i}^{T}}{G D P_{0}^{T}}\right)
\end{gathered}
$$

\section{RESUlTS}

\section{A. Dynamic Panel Data Results}

The summary of the regression results for the three models is stated in Table 2. The first model indicates that carbon emission positively and significantly (by 5\%) affects the economic growth; an increase of $1 \%$ in carbon emissions increases the GRDP by $0.15 \%$. This relationship shows that provinces in Indonesia are still in the early phase of EKC hypothesis - economic growth is still the main priority and environmental degradation tends to worsen as its by product [9]. On the other hand, the rising of emissions shows the increasing level of production activity in a region, which also leads to higher GRDP [5]. In Model 1, the Gross Fixed Capital Formation (GFCF), as a proxy of capital stock, statistically has significant positive relation with the GRDP. As mentioned above, in the Cobb-Douglas equation, capital is one of the main

\begin{tabular}{|c|c|c|c|}
\hline $\begin{array}{l}\text { Independent } \\
\text { Variables }\end{array}$ & $\begin{array}{l}\text { Model } 1 \\
\text { GDP } \\
\text { per Capita }\end{array}$ & $\begin{array}{l}\text { Model } 2 \\
\text { Energy } \\
\text { Consumption } \\
\text { per Capita }\end{array}$ & $\begin{array}{l}\text { Model } 3 \\
\mathrm{CO}_{2} \text { Emission } \\
\text { per Capita }\end{array}$ \\
\hline $\begin{array}{l}\text { Gross Regional } \\
\text { Domestic Product }\end{array}$ & & $\begin{array}{l}0.3003^{* * *} \\
(0.99)\end{array}$ & $\begin{array}{l}0.4162 \\
(0.368)\end{array}$ \\
\hline $\begin{array}{l}\text { Gross Regional } \\
\text { Domestic Product (-1) }\end{array}$ & $\begin{array}{l}0.5838^{* * * *} \\
(0.112)\end{array}$ & & \\
\hline $\mathrm{CO}_{2}$ Emission & $\begin{array}{l}0.1491 * * \\
(0.065)\end{array}$ & $\begin{array}{l}0.2204 * * * \\
(0.076)\end{array}$ & \\
\hline $\mathrm{CO}_{2}$ Emission (-1) & & & $\begin{array}{l}0.0504 \\
(0.088)\end{array}$ \\
\hline Energy Consumption & $\begin{array}{l}0.1290 \\
(0.091)\end{array}$ & & $\begin{array}{l}0.916^{* *} \\
(0.483)\end{array}$ \\
\hline Energy Consumption (-1) & & $\begin{array}{l}0.4176^{* * * *} \\
(0.06)\end{array}$ & \\
\hline $\begin{array}{l}\text { Gross Fixed Capital } \\
\text { Formation }\end{array}$ & $\begin{array}{l}0.0356 * * \\
(0.016)\end{array}$ & $\begin{array}{l}0.0409 \\
(0.025)\end{array}$ & \\
\hline Trade Openness & & & $\begin{array}{l}0.0929 \\
(0.092)\end{array}$ \\
\hline Population & & & $\begin{array}{l}1.2724 * * * \\
(0.497)\end{array}$ \\
\hline Labor Force & $\begin{array}{l}0.0059 \\
(0.006)\end{array}$ & $\begin{array}{l}0.0054 \\
(0.006)\end{array}$ & \\
\hline Loan Ratio to GRDP & & $\begin{array}{l}-0.7432 * * * \\
(0.155)\end{array}$ & \\
\hline Constant & $\begin{array}{l}1.2321^{* * * *} \\
(0.371)\end{array}$ & $\begin{array}{l}-1.4142 * * * \\
(0.277)\end{array}$ & $\begin{array}{l}-10.8743 \text { *** } \\
(2.914)\end{array}$ \\
\hline Obs & 552 & 544 & 636 \\
\hline Prob $>\mathrm{chi}^{2}$ & 0.0000 & 0.0000 & 0.0000 \\
\hline Arrelano-Bond test & 0.0178 & 0.0012 & 0.0078 \\
\hline
\end{tabular}
important determinants of the output-beside labor [13].

TABLE II. REGRESSION RESULTS

$*$ ) indicates significant at $10 \%$ level, **) indicates significant at $5 \%$ level, and ***) indicates significant at $1 \%$ level.
In Model 2, the result shows that GRDP, environmental degradation and loan ratio to GRDP are statistically significant to the energy consumption per capita. The GRDP shows a positive relationship - $1 \%$ increase of GRDP tends to increase energy consumption by $0.3 \%$. Carbon emissions also show a positive relation with energy consumption and this conjugates well with the fact that some carbon emissions are derived from energy consumption. On the other hand, loan ratio to GRDP has a negative association with the energy consumption. The coefficient demonstrates that there is $0.47 \%$ reduction of energy consumption per capita for every $1 \%$ increase in loan. This relation implies that financial development, represented by the loan ratio, promotes the usage of efficient energy since the fund is used to purchase newest appliances, so that the energy consumption becomes more efficient [14] [15].

In the last model, it can be seen that variables of energy consumption and population statistically give significant influence to the carbon emissions. The result shows that an increase of $1 \%$ on energy consumption per capita makes almost a $1 \%$ increase in carbon emissions. In addition, the regression result also indicates that as population continues to grow, energy use and carbon emissions in most regions do the same.

\section{B. Decomposition Results}

As seen in Fig. 1, Indonesia mostly had a steady economic growth, after the downfall of Indonesia's economy caused by 1998 Asian Crisis, in average amounting to 5.3\% per year. As for its energy intensity, the finding revealed a negative growth of $1 \%$ per year, which means that less of energy is needed in order to produce a rupiah of GDP. This indicates a good sign of Indonesia's energy becoming greener at a constant rate. As for carbon content of energy, its high fluctuation rate plays a significant role in influencing the total carbon emitted per year.

The detailed year-by-year decomposition results from LDMI are presented in Table 3. The accumulated effects for four periods are also shown in the lower section of Table 3 . Based on these results, even though in the last few years there were fluctuations of carbon emission, but in general, from 2008 to 2014, Indonesia emitted 30 million tons more carbon each year. As shown in Table 3, economic productivity and carbon content of energy plays a significant role in emitting more carbon emissions. Energy intensity, on the other hand, is the most significant factor in decreasing carbon emissions in Indonesia's

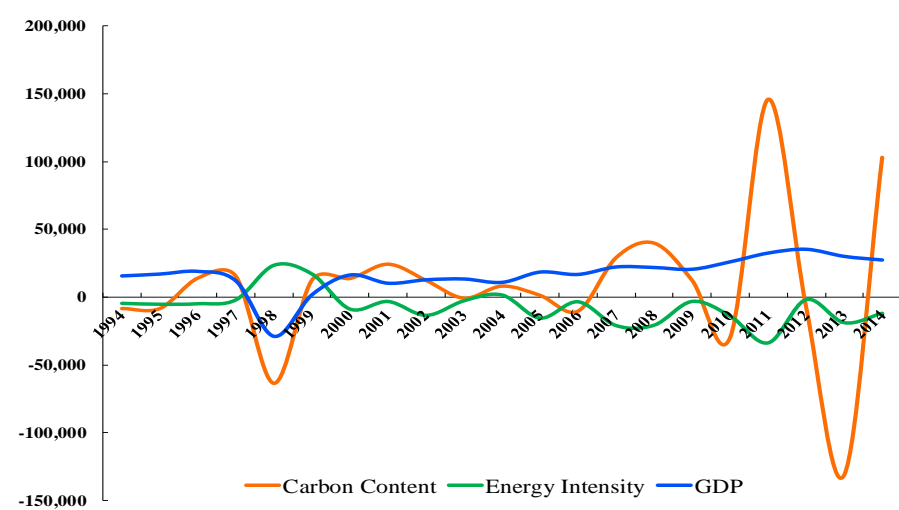

Fig. 1. Proportion of Kaya identity in total carbon emissions 
TABLE III. DECOMPOSITION RESULTS

\begin{tabular}{ccccc}
\hline Year & $\Delta \mathbf{C}_{\text {tot }}$ & $\Delta \mathbf{C}_{\text {cnt }}$ & $\Delta \mathbf{E}_{\text {int }}$ & $\Delta \mathbf{G D P}$ \\
\hline \hline $1993-1994$ & $2,812.58$ & $-8,218.74$ & $-4,473.36$ & $15,504.68$ \\
$1994-1995$ & $3,527.66$ & $-8,187.03$ & $-5,157.32$ & $16,872.01$ \\
$1995-1996$ & $28,349.55$ & $14,290.25$ & $-4,772.91$ & $18,832.21$ \\
$1996-1997$ & $25,368.35$ & $15,434.01$ & $-1,850.50$ & $11,784.84$ \\
$1997-1998$ & $-68,448.22$ & $-63,432.46$ & $23,801.05$ & $-28,816.81$ \\
$1998-1999$ & $31,787.44$ & $12,824.43$ & $17,262.34$ & $1,700.67$ \\
$1999-2000$ & $21,410.39$ & $13,983.27$ & $-8,767.19$ & $16,194.31$ \\
$2000-2001$ & $31,509.57$ & $24,479.88$ & $-3,114.69$ & $10,144.38$ \\
$2001-2002$ & $11,819.00$ & $12,542.02$ & $-13,397.39$ & $12,674.36$ \\
$2002-2003$ & $10,075.49$ & -605.55 & $-2,564.15$ & $13,245.19$ \\
$2003-2004$ & $20,822.65$ & $8,311.04$ & $1,716.91$ & $10,794.70$ \\
$2004-2005$ & $4,367.15$ & $1,464.49$ & $-15,422.48$ & $18,325.14$ \\
$2005-2006$ & $3,127.36$ & $-10,126.70$ & $-3,339.85$ & $16,593.92$ \\
$2006-2007$ & $30,404.34$ & $29,304.47$ & $-20,977.22$ & $22,077.09$ \\
$2007-2008$ & $41,014.12$ & $40,036.41$ & $-20,716.75$ & $21,694.46$ \\
$2008-2009$ & $29,861.29$ & $12,542.63$ & $-3,076.41$ & $20,395.07$ \\
$2009-2010$ & $-17,660.65$ & $-29,605.44$ & $-13,880.91$ & $25,825.70$ \\
$2010-2011$ & $144,630.50$ & $146,177.84$ & $-33,824.74$ & $32,277.40$ \\
$2011-2012$ & $26,145.02$ & $-7,196.98$ & $-1,708.40$ & $35,050.40$ \\
$2012-2013$ & $-120,159.55$ & $-131,195.68$ & $-18,815.84$ & $29,851.97$ \\
$2013-2014$ & $118,621.40$ & $103,326.50$ & $-11,886.86$ & $27,181.75$ \\
\hline $1993-1997$ & $60,058.14$ & $10,852.47$ & $-17,415.37$ & $66,621.04$ \\
$1998-2002$ & $96,526.40$ & $61,730.30$ & $-3,563.78$ & $38,359.89$ \\
$2003-2007$ & $58,721.50$ & $28,185.42$ & $-37,334.39$ & $67,870.47$ \\
$2008-2014$ & $181,438.01$ & $95,998.90$ & $-83,770.12$ & $169,209.23$ \\
\hline & & & & \\
\hline
\end{tabular}

current situation.

In order to promote growth, economic productivity represented by GDP is expected to have a steady growth at $5.3 \%$ per year. So, the government's controls in carbon emission reduction are only possible in maintaining energy intensity of economic and carbon content of energy. Although the rate of energy intensity has already been declining, Indonesia needs to further intensify its greener growth. Assuming that $2 \%$ of decline rate each year can be successfully achieved, by 2030 there will be $28 \%$ carbon emission reduction from energy intensity. This means that, to reach the NDC target, the carbon content of energy reduction needs to be accelerated until $4.5 \%$ each year. Thus, in previous years this carbon content of energy can be reduced up to more than $20 \%$ in one year. This assumption is possible to be achieved; by 2030, the carbon emissions will reduce by $29.5 \%$.

\section{CONCLUSION AND POLICY IMPLICATIONS}

Even though the studies on economic growth, carbon emissions, and energy consumption have improved over last few years, there is no study investigating the relationship of these variables using simultaneous equation models for 34 provinces in Indonesia. The regressions are based on time data panel from 1993 to 2014. This study divides the global panel analysis into three specifications with the dependent variables are economic growth, carbon emissions, and energy consumptions. The empirical results show that carbon emissions and GFCF have significant relationship with GDP per capita. It implies that the economic activities and capital is the key for each local government to boost local income. In addition, variables that influence per capita energy consumption in Indonesia are GRDP, carbon emissions, and loan ratio to GRDP. Consequently, in pursuance of lowering the environmental degradation, the government should control the usage of energy. The government should promote the usage of efficient renewable energy.

Based on the decomposition results of Kaya identity, carbon content of energy plays an important role in contributing to Indonesia total carbon emissions. On contrary, energy intensity of economic over the past decade showed a significant impact in reducing total carbon emissions. Using the average growth rate of GDP, in order to successfully achieved NDC target, Indonesia needs to reduce their carbon content of energy by $4 \%$ per year and further improve the reduction of energy intensity into $2 \%$ reduction per year. By then, in 2030, Indonesia's total carbon emissions are expected to be $29.5 \%$ lower than the current situation.

\section{REFERENCES}

[1] International Energy Agency, "Renewable Energy Medium-Term Market Report 2016," 2016.

[2] Ministry of Energy and Mineral Resources Republic of Indonesia, "2017 Handbook of Energy \& Economic Statistics of Indonesia," Jakarta, 2017.

[3] BPS-Statistics Indonesia, Statistical Yearbook of Indonesia 2017. Jakarta: BPS-Statistics Indonesia, 2017.

[4] A.K. Richmond and R.K. Kaufmann, "Is there a turning point in the relationship between income and energy use and/or carbon emissions?," Ecological Economics, vol. 56, no. 2, pp. 176-189, February 2006.

[5] V. C. Jaunky, "The $\mathrm{CO}_{2}$ emissions-income nexus: evidence from rich countries," Energy Policy, vol. 39, no. 3, pp. 1228-1240, March 2011.

[6] Lanouar Charfeddine and Karim B. Khediri, "Financial development and environmental quality in UAE: Cointegration with structural breaks," Renewable and Sustainable Energy Reviews, vol. 55, pp. 1322-1335, March 2016.

[7] M. Kahia, M. S. B. Aissa, and L. Charfeddine, "Impact of renewable and non-renewable energy consumption on economic growth: New evidence from the MENA Net Oil Exporting Countries (NOECs)," Energy, vol. 116, pp. 102115, December 2016.

[8] S. Anwar and L. P. Nguyen, "Foreign direct investment and economic growth in Vietnam," Asia Pacific Business Review, vol. 16, no. 1-2, pp. 183-202, April 2010. 
[9] A. Omri, D. K. Nguyen, and C. Rault, "Causal interactions between CO 2 emissions, FDI, and economic growth: Evidence from dynamic simultaneous-equation models," Economic Modelling, vol. 42, pp. 382-389, October 2014.

[10] J. W. Lee, "The contribution of foreign direct investment to clean energy use, carbon emissions and economic growth," Energy Policy, vol. 55, pp. 483-489, April 2013.

[11] A. Omri, " $\mathrm{CO}_{2}$ emissions, energy consumption and economic growth nexus in MENA countries: evidence from simultaneous equations models," Energy economics, vol. 40, pp. 657-664, November 2013.

[12] M. Arellano and S. Bond, "Some tests of specification for panel data: Monte Carlo evidence and an application to employment equations," The review of economic studies, vol. 58, no. 2, pp. 277-297, April 1991.

[13] Luiz R. De Mello Jr, "Foreign direct investment in developing countries and growth: A selective survey," The Journal of Development Studies, vol. 34, pp. 1-34, October 1994.

[14] F. Islam, M. Shahbaz, A. U. Ahmed, and M. M. Alam, "Financial development and energy consumption nexus in Malaysia: a multivariate time series analysis," Economic Modelling, vol. 30, pp. 435-441, January 2013.

[15] M. Shahbaz and H. H. Lean, "Does financial development increase energy consumption? The role of industrialization and urbanization in Tunisia," Energy policy, vol. 40, pp. 473-479, January 2012. 